\title{
Sequencing and promoter analysis of the nifENXorf3orf5fdxAnifQ operon from Azospirillum brasilense Sp7
}

\section{D.P. Potrich ${ }^{1}$, \\ T.A. Bressel2, I.S. Schrank ${ }^{2}$ and L.M.P. Passaglia ${ }^{1}$}

\author{
Departamentos de ${ }^{1}$ Genética and ${ }^{2}$ Biologia M olecular e Biotecnologia, \\ Centro de Biotecnologia, Universidade Federal do Rio Grande do Sul, \\ Porto Alegre, RS, Brasil
}

\section{Correspondence \\ L.M.P. Passaglia \\ Centro de Biotecnologia \\ Departamento de Genética, UFRGS \\ Av. Bento Gonçalves, 9500 \\ Prédio 43421 \\ Caixa Postal 15005 \\ 91501-970 Porto Alegre, RS \\ Brasil \\ E-mail: luciane@ dna.cbiot.ufrgs.br}

Research supported by CNPq and FAPERGS.

Received April 12, 2001 Accepted July 25, 2001

\section{Abstract}

A 40-kb DNA region containing the major cluster of nif genes has been isolated from the Azospirillum brasilense Sp7 genome. In this region three nif operons have been identified: nifHDKorf1Y, nifENXorf3orf5fdxAnifQ and orf2nifUSVorf4. The operons containing nifENX and nifUSV genes are separated from the structural nifHDKorf1Y operon by about $5 \mathrm{~kb}$ and $10 \mathrm{~kb}$, respectively. The present study shows the sequence analysis of the 6045-bp DNA region containing the nifENX genes. The deduced amino acid sequences from the open reading frames were compared to the nif gene products of other diazotrophic bacteria and indicate the presence of seven ORFs, all reading in the same direction as that of the nifHDKorflY operon. Consensus $\sigma^{54}$ and NifA-binding sites are present only in the promoter region upstream of the nifE gene. This promoter is activated by NifA protein and is approximately two-times less active than the nifH promoter, as indicated by the $\beta$-galactosidase assays. This result suggests the differential expression of the nif genes and their respective products in Azospirillum.

\section{Introduction}

The biological process of nitrogen fixation is catalyzed by the nitrogenase enzyme, an enzyme complex containing the nitrogenase reductase (Fe-protein) and dinitrogenase (MoFe-protein). The Fe-protein (NifH) is a dimer of identical subunits, which contains a single $4 \mathrm{Fe}-4 \mathrm{~S}$ cluster. The $\mathrm{MoFe}-$ protein is an $\alpha_{2} \beta_{2}$ tetramer (NifD and NifK) including two iron-molybdenum cofactors (FeMoco) and about 16 additional iron and acid-labile sulfur irons (1). Twenty nif genes have been described in the extensively studied nitrogen-fixing organism Klebsiella pneu- moniae, but they are not all essential for $\mathrm{N}_{2-}$ fixing activity (2). These genes are located on a contiguous $24-\mathrm{kb}$ chromosomal DNA fragment and organized into several operons (2). The observation that the nucleotide sequence and protein structure of dinitrogenase and dinitrogenase reductase are conserved among all nitrogen-fixing organisms allowed the identification and cloning of homologous sequences from several other diazotroph organisms (2-6). However, the organization of the nif genes has been observed to diverge among the different diazotrophic bacteria. In some cases, the nifHDK genes are transcribed as a single unit, as 
observed in several fast-growing rhizobia including Sinorhizobium meliloti (7) and Rhizobium leguminosarum (8) and in the newly described nif cluster from Gluconacetobacter diazotrophicus (9). In other cases, the nifHDK operon contains other nif genes, as reported for Azotobacter vinelan$\mathrm{dii}$, where they constitute an operon together with nifTY, orf1 and orf2 (3), Herbaspirillum seropedicae, where they form a large operon composed by nifHDKENXorflorf2 (10), and Azospirillum brasilense, where they are clustered with orfl and nifY (4). In other cases, they are separated into two different regions (nifH and nifDK), as shown in the slow-growing species Bradyrhizobium japonicum (11) and Bradyrhizobium sp (Vigna) (cowpea Bradyrhizobia) $(12,13)$.

In all diazotrophics several other genes have been reported to be essential for producing an active nitrogenase. The gene products of nifE and nifN are involved in synthesis of the FeMoco of nitrogenase and are structurally related to the products of the nitrogenase genes nifDK (14). The nifEN genes from $K$. pneumoniae are clustered into a single operon, together with nifX, downstream from the nifHDKTY operon (2), and are expressed from the promoter located upstream of the nifE gene $(14,15)$. In Rhodobacter capsulatus, the nifENXorf4orf5nifQ operon contains the nif $X$ and nif $Q$ genes (16). Transposon insertions into the nifE and nif $N$ genes yielded the $\mathrm{Nif}^{-}$phenotype in $K$. pneumoniae (17) and A. brasilense $(18,19)$. However, transposon insertion in $R$. capsulatus nif $X$ showed that its product is not essential for nitrogen fixation (20). Recent results indicate that the Azotobacter vinelandii NifX protein participates in FeMoco synthesis in vitro (21). The orf4 of $R$. capsulatus encodes a ferredoxin-like protein and is homologous to orf 3 found in $A$. vinelandii as part of the operon nifENXorf3orf4 (3).

Bacteria of the genus Azospirillum are diazotrophs capable of fixing nitrogen in free-living state or associated with roots of economically important grasses (22). In A. brasilense three nif operons, nifHDKorf1Y, nifENXorf3orf5fdxAnifQ and orf2nifUSV orf 4 , have been identified and their sequences have been determined ( 4,23 , and the present study). The operons encompassing the nifENX and nifUSV genes are separated from the structural nifHDKorf1Y operon by about 5 and $10 \mathrm{~kb}$, respectively (23). A putative -24/-12 promoter element has been found in the promoter region of the nifH, nifE and nif $U$ genes. The promoter site of nifH was studied in more detail and showed two overlapping NifA-binding sites, where the examination of activation of the mutant nifH promoter by NifA revealed that the integrity of the NifA-binding site closer to nifH is required for the most efficient activation (24).

In the present study, we have determined the nucleotide sequence of the $A$. brasilense Sp7 nifENX genes, three open reading frames (orf3, orf5 and $f d x A$ ) and the nif $Q$ gene, which constitute an operon transcribed from a single promoter upstream of the nifE gene. We have also shown that this promoter is activated by NifA protein and is less active than the nifH promoter, as measured by $B-$ galactosidase promoter fusion.

\section{Material and Methods}

\section{Bacterial strains, plasmids and growth conditions}

The bacterial strains and plasmids used in the present study are listed in Table 1. LB medium (25) was used for growing $E$. coli strains at $37^{\circ} \mathrm{C}$. A. brasilense $\mathrm{Sp} 7$ strain was grown at $30^{\circ} \mathrm{C}$ in either $\mathrm{LB}$ medium or MMAb minimal medium (26) using $0.5 \%$ malate as carbon source. For the B-galactosidase assays, A medium was used for growing $E$. coli MC1061 strain at $28^{\circ} \mathrm{C}$, as indicated by Sambrook et al. (25). The medium was supplemented with the antibiotics tetracycline and/or ampicillin when necessary, at 
concentrations of 10 and $100 \mathrm{~g} / \mathrm{ml}$, respectively.

\section{DNA manipulations and sequencing}

Plasmid DNA preparation, restriction enzyme analysis, transformation and electrophoresis on agarose or polyacrylamide gel were performed as described by Sambrook et al. (25). Restriction endonucleases and other enzymes were purchased from Pharmacia (Uppsala, Sweden) or Gibco/BRL (Gaithersburg, MD, USA) and used according to the manufacturer's instructions.

The nucleotide sequence was determined by the chain-termination method of Sanger et al. (as described in Ref. 27) using ${ }^{33} \mathrm{P}$ -
ddNTPs and the ThermoSequenase radiolabeled terminator cycle sequencing kit (Amersham Pharmacia Biotech, Uppsala, Sweden). Defined restriction fragments from the EcoRI/ Pst I A. brasilense DNA region shown in Figure 1 were subcloned to generate several sequencing plasmids (Table 1). The junctions of all subclones were checked by sequencing directly from the larger parental plasmid, pWY1 (this laboratory), using oligonucleotides generated from the sequences already obtained. All manual sequencing data were confirmed by using the Molecular Genetics Instrumentation Facility, University of Georgia, Atlanta, GA, USA. Analysis of DNA sequences and comparison with nucleotide and deduced protein sequences from

Table 1. Bacterial strains and plasmids used in the present study.

\begin{tabular}{|c|c|c|c|}
\hline Bacteria & Strain & Relevant characteristics & Reference \\
\hline Azospirillum brasilense & Sp7 & ATCC $29145, \mathrm{Amp}^{\mathrm{R}}$ & 22 \\
\hline \multirow[t]{2}{*}{ Escherichia coli } & XL1-Blue & $\begin{array}{l}\text { supE44 hsdR17 recAl endA1 } \\
\text { gyrA46 thi relA1 lac-F'[proAB } \\
\text { lacl9 lacZ } 15 \text { Tn10(tet')] }\end{array}$ & 25 \\
\hline & MC1061 & $\begin{array}{l}\text { hsdR mcrB araD } 1394 \\
\text { (araABC-leu) } 7679 \\
\Delta \text { lacX74 galU galK rpsL thi }\end{array}$ & 28 \\
\hline Plasmid & \multicolumn{2}{|c|}{ Relevant characteristics } & Reference \\
\hline pBluescript & \multicolumn{2}{|l|}{$A m p^{R}$} & Stratagene \\
\hline pUC18 & \multicolumn{2}{|l|}{$A m p^{R}$} & 25 \\
\hline pCK3 & \multicolumn{2}{|c|}{$\begin{array}{l}\text { pRK290 derivative containing the } \\
\text { Klebsiella pneumoniae nifA gene }\end{array}$} & 29 \\
\hline pMC1403 & \multicolumn{2}{|c|}{ translational fusion lacZ plasmid } & 28 \\
\hline $\mathrm{pMCH}$ & \multicolumn{2}{|c|}{$\begin{array}{l}\text { pMC1403 derivative containing } \\
\text { the } A \text {. brasilense nifH promoter }\end{array}$} & 24 \\
\hline pMCE & \multicolumn{2}{|c|}{$\begin{array}{l}\text { pMC1403 derivative containing the } \\
\text { A. brasilense nifE promoter }\end{array}$} & Present paper \\
\hline pWY1 & \multicolumn{2}{|c|}{$\begin{array}{l}\text { pUC18 derivative containing a } 5.8-\mathrm{kb} \\
\text { EcoRI/Pstl A. brasilense DNA fragment }\end{array}$} & This laboratory \\
\hline pKS2.2 & \multicolumn{2}{|c|}{$\begin{array}{l}\text { pBSKS+ derivative containing a } 2.2-k b \\
\text { EcoRI/HindllI DNA fragment }\end{array}$} & Present paper \\
\hline pKS0.8 & \multicolumn{2}{|c|}{$\begin{array}{l}\text { pBSKS+ derivative containing a 0.8-kb } \\
\text { HindllI/Sall DNA fragment }\end{array}$} & Present paper \\
\hline pKS1.5 & \multicolumn{2}{|c|}{$\begin{array}{l}\text { pBSKS+ derivative containing a } \\
1.5-\mathrm{kb} \text { Sall DNA fragment }\end{array}$} & Present paper \\
\hline pKS1.3 & \multicolumn{2}{|c|}{$\begin{array}{l}\text { pBSKS+ derivative containing a } \\
\text { 1.3-kb Sall/Pstl DNA fragment }\end{array}$} & Present paper \\
\hline
\end{tabular}


other organisms were performed using the GCG (Wisconsin Package Version 9.0, Genetics Computer Group, Madison, WI, USA) computer programs (licensed to CENARGEN-EMBRAPA, Brasília, DF, Brazil).

\section{PCR}

The 590-bp DNA fragment containing the promoter region of the nifE gene was obtained by PCR with A. brasilense Sp7 total DNA as a template. The oligonucleotides used for PCR were 5' CGCCGCCAAC GACGAGGTCAAGAA 3', which corre- sponds to the C-terminal region of the $m c p A b$ gene (Schneider $\mathrm{C}$, unpublished results), and 5' GGTGGAGCAACCCGGCTCGTT 3', which corresponds to the beginning of the nifE-coding region. The amplified fragment was cloned into the HincII site of the pBluescript KS+ vector and completely sequenced to check the absence of mutations.

\section{Plasmid construction and B-galactosidase assays}

The strategy used to obtain the pMCE plasmid is shown in Figure 1. DNA from the pBluescript KS+ plasmid carrying the 590-
Figure 1. Physical map of the nif gene cluster in the genome of Azospirillum brasilense (A) and cloning strategy of the nifE promoter region (B). A, Represents the organization of nif and other genes in the chromosome of $A$. brasilense. Arrows represent the positions and direction of transcription of the operons. The nifENXorf3orf5fdXAnifQ operon is shown in detail in the lower part of the figure. Each restriction fragment was cloned into the pUC18 plasmid, as described in Table 1. B, Cloning strategy of the nifE promoter region into the pMC1403 plasmid. E, EcoRl; $\mathrm{H}$, HindlII; P, Pstl; B, BamHI; S, Sall.

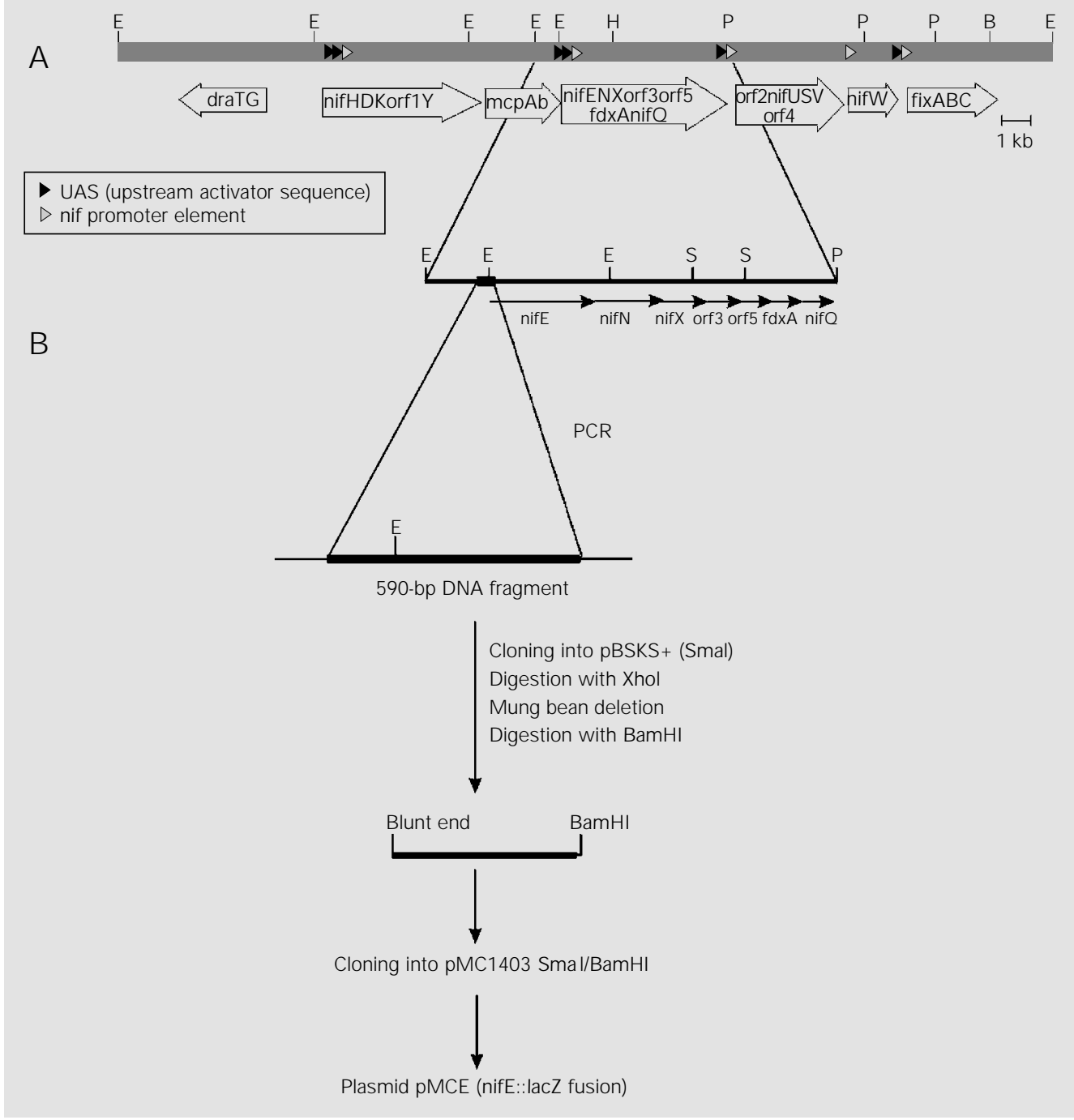


bp PCR amplified DNA fragment (described above) was digested with $\mathrm{XhoI}$ (vector site) followed by mung bean deletion to generate a shortened blunt-end fragment. This linear pBluescript recombinant plasmid was further digested with BamHI and the blunt-end/ BamHI fragment was cloned into the pMC1403 SmaI/BamHI-digested vector containing the lac $Z$ translational fusion. The recombinant $\mathrm{pMCE}$ was used to monitor the activity of the nifE promoter by measuring Bgalactosidase activity in E. coli MC1061 (28). The K. pneumoniae NifA protein synthesized constitutively was provided by the pCK3 plasmid (29). Plasmid pMCH, containing a nifH::lacZ fusion (24), was used as a positive control.

The $\beta$-galactosidase activities of strains carrying the nif-lac $Z$ promoter fusions were determined according to the procedure of Miller et al. (as described in 25 ) at $28^{\circ} \mathrm{C}$.

\section{Nucleotide sequence accession number}

The nucleotide sequence of the nifENX orf3orf5fdxAnifQ operon of A. brasilense Sp7 has been deposited in Genbank under accession No. AF361867 along with the predicted amino acid sequence.

\section{Results}

The nifENXorf3orf5fdxAnifQ genes of $A$. brasilense $\mathrm{Sp} 7$ are in the same transcriptional unit and are expressed from a $\sigma^{54}$ promoter upstream of nifE.

Tn5 mutagenesis of the A. brasilense DNA regions downstream from the nifHDK operon revealed a region of approximately 6000 bp containing the nifENX genes (19). In this region seven complete open reading frames (ORFs) were identified, all reading in the same direction as that of the nifHDK operon, as indicated in Figure 1. The assignment of genes was based on deduced amino acid sequence identities to the nif gene products of $K$. pneumoniae and several other diazotrophic bacteria. The likely initiation codon for all seven genes or ORFs is an ATG preceded in each case by a characteristic AG-rich ribosome-binding site.

Only one region within the 6045-bp sequence displays close similarity to the $\sigma^{54}$ recognition consensus sequence (15) and occurs at $45 \mathrm{bp}$ upstream from the translational initiation codon of nifE. We identified two nif-specific upstream activator sequences, TGT- $\mathrm{N}_{10}$-ACA, characteristic of NifA-dependent promoters (30), located 72 and 45 bp upstream of the putative $\sigma^{54}$ dependent promoter, respectively.

The A. brasilense nifE-, nifN- and nifXcoding regions are 1413, 1398 and 471 nucleotides long, respectively, and predict polypeptides of 417 residues corresponding to NifE, 466 residues corresponding to NifN, and 157 residues corresponding to NifX proteins. An overlapping coding region was observed between nif $N$ and nif $X$. The predicted amino acid sequences from $A$. brasilense nifE, nifN and nifX genes were compared to their counterpart sequences from other diazotrophic organisms, as shown in Appendix 1 (I, II and III) (see pages 13881393). The identity of the deduced A. brasilense NifE, NifN and NifX amino acid sequences is distributed over the entire length of corresponding proteins. Conserved cysteine residues (marked by black dots in Appendix 1) are present in all NifE, NifN and NifX proteins, except for some cysteine residues that were not found in the H. seropedicae NifE protein (11; Appendix 1(I)). The highest similarity level was found between A. brasilense and G. diazotrophicus NifE (9) proteins $(60.8 \%)$, A. brasilense and B. japonicum NifN (31) proteins (50.3\%), and $A$. brasilense and $H$. seropedicae NifX (10) proteins $(55 \%)$.

In addition to the nifENX genes, four other ORFs were identified (Figure 1). The first one, orf3, revealed high similarity with G. diazotrophicus orf1 (59.6\%) (9). The contiguous ORF, orf5, showed $61.8 \%$ similarity 
Figure 2. In vivo expression of nif'-'lacZ from the nifE (E) and nifH $(\mathrm{H})$ promoters in the E. coli MC1061 strain in the presence (+ NifA) or absence of the NifA activator protein provided by pCK3 plasmid. Expression of nif'-'lacZ fusion was measured as a function of the $O_{600}$ for cultures grown in A medium (see Material and Methods). In each case, three data points (between $\mathrm{OD}_{600}$ of 0.2 and 0.6 ) were used to determine the slope of the line, which reflects the differential rate of nif'-'lac $Z$ expression. Curve labeled MC (which overlaps the curve from the nifH promoter in the absence of NifA) gives data for the E. coli MC1061 host strain (negative control). to Azorhizobium caulinodans orfl (32) and $61.2 \%$ similarity to Acetobacter diazotrophicus orf2 (9). The third ORF was homologous to a ferredoxin-like protein from $R$. capsulatus (54.9\% similarity) (16) and a ferredoxin III protein from the cyanobacterium Plectonema boryanum (57.3\% similarity) (33) and was assigned to $f d x A$. The comparison between these ORFs and their homologous counterparts is shown in Appendix 2 (see pages 1394 and 1395).

The last ORF identified within the sequenced region of $A$. brasilense encoded a protein of 196 amino acids and the alignment of the deduced amino acid sequence of this A. brasilense ORF with that of NifQ proteins from K. pneumoniae (34), R. capsulatus (16), Acetobacter diazotrophicus (9), Enterobacter agglomerans (35), Azotobacter vinelandii (4) and Rhizobium sp (36) revealed an overall ranging of homology from 30.5 to $37.5 \%$ of similarity (Appendix 1(IV)). The identity between the NifQ proteins was mainly restricted to the $\mathrm{C}$-terminal part, including a typical cysteine motif (marked in Appendix 1) found in all NifQ proteins identified to date.

Inverted repeat structures were detected only in two regions at 110 and 173 nucleo-

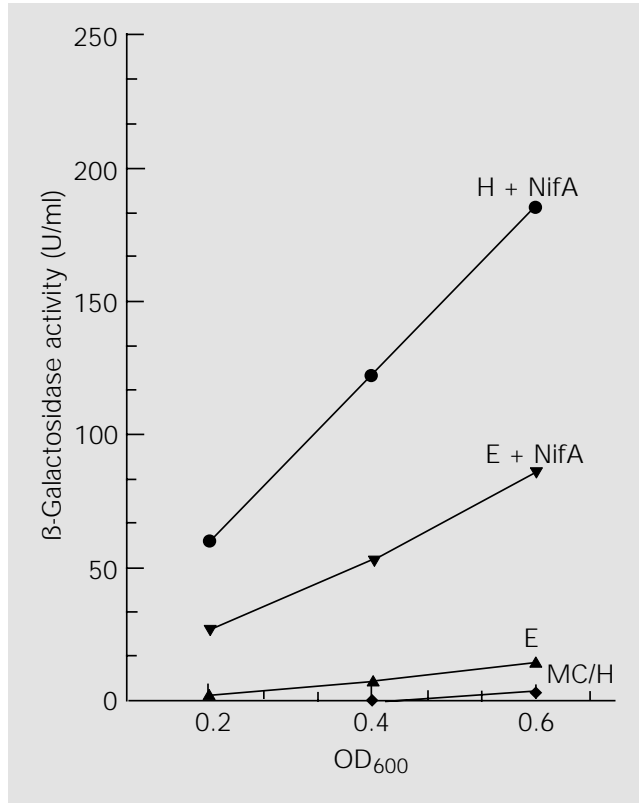

tides from the nifQ stop codon. Messenger RNA transcribed from these regions could potentially form a characteristic stem-andloop secondary structure and may be involved in the termination of transcription. No other ORF was found in the region between the end of the nifQ gene and the beginning of the orf2nifUSVorf4 operon.

\section{The nifE promoter activity is dependent on NifA protein}

To verify the functionality of the putative nif promoter identified in the region upstream of the nifE initiation codon we amplified by PCR a 590-bp DNA fragment containing the regulatory region of the nifENX orf3orf5fdxAnifQ operon. This fragment was cloned into the pMC1403 translational fusion plasmid and the recombinant pMCE was used to monitor the activity of the nifE promoter by measuring $\beta$-galactosidase activity in E. coli MC1061 (as described in Material and Methods). As shown in Figure 2 , the $B$-galactosidase activity driven by the A. brasilense nifE promoter was only detected if the NifA protein was provided in trans via the $\mathrm{pCK} 3$ plasmid that promotes constitutive expression of the $K$. pneumoniae NifA. In fact, E. coli MC1061 harboring pMCE, but not pCK3, showed only background levels of $\beta$-galactosidase activity (Figure 2). These results demonstrate that the activity of the nifE promoter is dependent on NifA.

We also used the pMCH plasmid (24) as a positive control and we were able to compare the activities of both $A$. brasilense nif promoters. The nifE promoter is approximately two times less active than the nifH promoter, as indicated by the $\beta$-galactosidase assays (Figure 2, compare E + NifA with $\mathrm{H}+\mathrm{NifA})$.

\section{Discussion}

Nitrogen fixation genes, nif genes, are 
frequently clustered into different transcriptional units. The overall organization of nif operons also shows some conservation among the genomes of diazotrophic bacteria. In A. brasilense the distribution of the nifENX genes within the operon resembles the organization described for other diazotrophic organisms. NifE and NifN proteins were found to be similar to those present in other $\alpha$-group Proteobacteria. NifX was more similar to the gene product of $H$. seropedicae, a member of the B-group of Proteobacteria, than the product of the $\gamma$-group members. However, NifQ was similar to the NifQ from Azotobacter vinelandii which belongs to the $\gamma$-group of Proteobacteria.

In some members of the Proteobacteria the nif genes, initially described in $K$. pneumoniae, are organized in operons together with different ORFs. In A. brasilense the organization of nifENXorf3orf5fdxAnifQ is similar to that found in G. diazotrophicus. In fact, the organization of the nif gene in $G$. diazotrophicus and A. brasilense seems to be highly similar: the nifENXorf3orf5fdx AnifQ operon containing orthologous proteins similarly organized, the presence of the mсрA gene in the surroundings of the nif cluster and the organization of the orf2nifUSV operon may indicate that both microorganisms share common characteristics, especially concerning their ability to enhance plant growth through the transfer of bacterially fixed nitrogen and the production of plant growth-stimulating factor(s) $(9,22)$. In addition, A. brasilense ORF3 was found to be similar to ORF1 from $H$. seropedicae present within the related nifENXorflorf2 gene cluster (10) and to ORF3 from A. vinelandii also located downstream to the nifX gene (3).

Several studies have demonstrated that nifEN are essential for the nitrogen fixation process. However, determination of the role of NifX during nitrogen fixation shows some differences concerning the diazotrophic bacteria. Araújo et al. (19), using insertional mutagenesis, obtained five Tn5 insertions in the region adjacent to the nifHDK genes of the $A$. brasilense genome. Four of them were located in the region corresponding to the nifEN genes and gave a $\mathrm{Nif}^{-}$phenotype. The fifth insertion which gave a $\mathrm{Nif}^{+}$phenotype was within the corresponding region of the A. brasilense nif $X$ gene, as further confirmed by sequencing analysis (present paper), and like the nifX gene from the B-group member $H$. seropedicae it proved not to be essential for nitrogen fixation (10). In contrast, NifX was shown to be essential for nitrogenase activity in an in vitro system in $A$. vinelandii (21), although under laboratory conditions, A. vinelandii nif $X$ showed a $\mathrm{Nif}^{+}$phenotype (3). To date, the nif $X$ mutant in all diazotrophs described has wild-type nitrogenase activity $(3,10,20)$.

Transcriptional and translational organization of the nif gene cluster of $A$. brasilense revealed conserved features. As found for the other A. brasilense nif/fix operons, sequence analysis of the nifENXorf3orf5fdx AnifQ revealed $\sigma^{54}$ and NifA-binding sites upstream of nifE, which are required, respectively, for nif promoter recognition and for nif gene transcriptional activation. Similarly to other nif genes, the A. brasilense nifE promoter is positively controlled by the activator NifA protein.

The nucleotide sequence and promoter analysis of the nifENXorf3orf5fdxAnifQ operon in A. brasilense revealed the presence of typical features in the deduced protein common among the related proteins in other organisms, as well as sequences upstream of nifE indicating a NifA-dependent transcriptional activation. Moreover, ORFs similar to orf 3 , orf5, and the putative $f d x A$ were also described in other groups of the Proteobacteria. 


\section{References}

1. Orme-J ohnson WH (1985). Molecular basis of nitrogen fixation. Annual Review of Biophysics and Biophysical Chemistry, 14: 419-459.

2. Amold W, Rump A, Klipp W, Priefer O \& Pühler A (1988). Nucleotide sequence of a 24,206 base-pair DNA fragment carrying the entire nitrogen fixation gene cluster of Klebsiella pneumoniae. J oumal of Molecular Biology, 203: 715-738.

3. J acobson MR, Brigle $K E$, Bennett $L T$, Setterquist RA, Wilson MS, Cash VL, Beynon J L, Newton WE \& Dean DR (1989). Physical and genetic map of the major nif gene cluster from Azotobacter vinelandii. J ournal of Bacteriology, 171: 1017-1027.

4. Passaglia LMP, Nunes CP, Zaha A \& Schrank IS (1991). The nifHDK operon in the free-living nitrogen-fixing bacteria Azospirillum brasilense sequentially comprises genes $H, D, K$, an 353 bp orf and gene $Y$. Brazilian J ournal of Medical and Biological Research, 24: 649-675.

5. Machado IMP, Yates MG, Machado HB, Souza EM \& Pedrosa FO (1996). Cloning and sequencing of the nitrogenase structural genes nifHDK of Herbaspirillum seropedicae. Brazilian J oumal of Medical and Biological Research, 29: 1599-1602.

6. Kessler PS \& Blank CLJ A (1998). The nif gene operon of the methalogenic archaeon Methanococcus maripaludis. J oumal of Bacteriology, 180: 1504-1511.

7. Corbin D, Barran L \& Ditta GS (1983). Organization and expression of Rhizobium meliloti nitrogen fixation genes. Proceedings of the National Academy of Sciences, USA, 80: 3005-3009.

8. Krol AJ M, Hontelez J GJ , Roozendaal B \& Kammen AV (1982). On the operon structure of the nitrogenase genes of Rhizobium leguminosarum and Azotobacter vinelandii. Nucleic Acids Research, 10: 4147-4157.

9. Lee S, Reth A, Meletzus D, Sevilla $M$ \& Kennedy C (2000). Characterization of a major cluster of nif, fix, and associated genes in a sugarcane endophyte, Acetobacter diazotrophicus. J ournal of Bacteriology, 182: 7088-7091.

10. Klassen G, Pedrosa FO, Souza EM, Yates MG \& Rigo LU (1999). Sequencing and functional analysis of the nifENXorf1orf2 gene cluster of Herbaspirillum seropedicae. FEMS Microbiology Letters, 181: 165-170.

11. Fischer HM \& Hennecke H (1984). Link- age map of the Rhizobium japonicum nifH and nifDK operons encoding the polypeptides of the nitrogenase enzyme complex. Molecular and General Genetics, 196: 537-540.

12. J agadish $M$, Yun AC, Noti J D, Folkerts $O$ \& Szalay AA (1985). Structural and functional organization of the nif region in the slow-growing, broad host-range cowpea Rhizobium strain IRc78. In: Szalay A \& Legocki RP (Editors), Advances in Molecular Genetics of Bacterial-Plant Interactions. Cornell University Publishers, Ithaca, NY, 27-31.

13. Yun AC \& Szalay AA (1984). Structural genes of dinitrogenase and dinitrogenase reductase are transcribed from two separate promoters in the broad host range cowpea Rhizobium strain IRc78. Proceedings of the National Academy of Sciences, USA, 81: 7358-7362.

14. Brigle KE, Weiss MC, Newton WE \& Dean DR (1987). Products of the iron-molybdenum cofactor-specific biosynthetic genes, nifE and nifN, are structurally homologous to the products of the nitrogenase molybdenum-iron protein genes, nifD and nifK. J oumal of Bacteriology, 169: 1547-1553.

15. Beynon J L, Cannon MC, BuchananWollaston AV \& Cannon FC (1983). The nif promoters of Klebsiella pneumoniae have a characteristic primary structure. Cell, 34: 665-671.

16. Moreno-Vivian $C$, Hennecke $S$, Pühler $A \&$ Klipp W (1989). Open reading frame 5 (ORF5), encoding a ferredoxin-like protein, and nifQ are cotranscribed with nifE, nifN, nifX, and ORF4 in Rhodobacter capsulatus. J ournal of Bacteriology, 171: 2591-2598.

17. Roberts GP, MacNeil T, MacNeil D \& Brill WJ (1978). Regulation and characterization of protein products coded by the nif (nitrogen fixation) genes of Klebsiella pneumoniae. J ournal of Bacteriology, 136: 267-279.

18. Galimand M, Perroud B, Delorme F, Paquelin A, Vieille C, Bozouklian $\mathrm{H}$ \& Elmerich C (1989). Identification of DNA regions homologous to nitrogen fixation genes nifE, nifUS and fixABC in Azospirillum brasilense Sp7. J ournal of General Microbiology, 135: 1-13.

19. Araújo EF, Zaha A, Schrank IS \& Santos DS (1988). Characterization of DNA segments adjacent to the nifHDK genes of Azospirillum brasilense Sp7 by Tn5 sitedirected mutagenesis. In: Klingmüller W
(Editor), Azospirillum IV: Genetics, Physiology and Ecology. Proceedings of the Fourth Bayreuth Azospirillum Workshop, Bayreuth, Germany, 16-25.

20. Moreno-Vivian C, Schmehl M, Masepohl B, Amold W \& Klipp W (1989). DNA sequence and genetic analysis of the Rhodobacter capsulatus nifENX gene region: homology between NifX and NifB suggests involvement of NifX in processing of the iron-molybdenum cofactor. Molecular and General Genetics, 216: 353-363.

21. Shah VK, Rangaraj P, Ranjini C \& Allen RM (1999). Requirement of NifX and other nif proteins for in vitro biosynthesis of the iron-molybdenum cofactor of nitrogenase. J oumal of Bacteriology, 181: 2797-2801.

22. Tarrand JJ, Krieg NR \& Döbereiner J (1978). A taxonomic study of the Spirillum lipoferum group, with descriptions of a new genus, Azospirillum gen. nov. and two species, Azospirillum lipoferum (Beijerinck) comb. nov. and Azospirillum brasilense $\mathrm{sp}$ nov. Canadian J ournal of Microbiology, 24: 967-980.

23. Frazzon J \& Schrank IS (1998). Sequencing and complementation analysis of the nifUSV genes from Azospirillum brasilense. FEMS Microbiology Letters, 159: 151-158.

24. Passaglia LMP, Schrank A \& Schrank IS (1995). The two overlapping Azospirillum brasilense upstream activator sequences have differential effects on nifH promoter activity. Canadian J oumal of Microbiology, 41: 849-854.

25. Sambrook J, Fritsch EF \& Maniatis T (1989). Molecular Cloning: A Laboratory Manual, 2. Cold Spring Harbor Laboratory Press, Cold Spring Harbor, NY, USA.

26. Vanstockem M, Michiels KW, Vanderleyden J \& Gool APV (1987). Transposon mutagenesis of Azospirillum brasilense and Azospirillum lipoferum: physical analysis of Tn5 and Tn5-Mob insertion mutants. Applied and Environmental Microbiology, 53: 410-415.

27. Sanger F, Nicklen $S \&$ Coulson AR (1977). DNA sequencing with chain-terminating inhibitors. Proceedings of the National Academy of Sciences, USA, 74: 54635467.

28. Casadaban MJ , Martinez-Arias A, Shapira S \& Chou J H (1983). B-galactosidase gene fusions for analysing gene expression in Escherichia coli and yeast. Methods in Enzymology, 100: 293-308.

29. Kennedy C \& Drummond MH (1985). Use 
of cloned nif regulatory elements from Klebsiella pneumoniae to examine nif regulation in Azotobacter vinelandii. J ournal of General Microbiology, 131: 17871795.

30. Buck M, Miller S, Drummond MH \& Dixon RA (1986). Upstream activator sequences are present in the promoters of nitrogen fixation genes. Nature, 320: 374-378.

31. Aguilar OM, Taormino J P, Thöny B, Ramseier T, Hennecke $H \&$ Szalay $A A$ (1990). The nifEN genes participating in FeMo cofactor biosynthesis and genes encoding dinitrogenase are part of the same operon in Bradyrhizobium species. Molecular and General Genetics, 224: 413-420.

32. Arigoni $\mathrm{F}$, Kaminski PA, Hennecke $\mathrm{H} \&$ Elmerich C (1991). Nucleotide sequence of the fixABC region of Azorhizobium caulinodans ORS571: similarity of the fixB product with eucaryotic flavoproteins, characterization of fixX, and identification of nifW. Molecular and General Genetics, 225: 514-520.
33. Schrautemeier B, Neveling $U \&$ Schmitz $S$ (1994). Characterization of the genome region encoding an fdxH-type ferredoxin and a new 2[4Fe-4S] ferredoxin from the nonheterocystous, nitrogen-fixing cyanobacterium Plectonema boryanum PCC 73110. J oumal of Bacteriology, 176: 10371046.

34. Buikema WJ, Klingensmith J A, Gibbons SL \& Ausubel FM (1987). Conservation of structure and location of Rhizobium meliloti and Klebsiella pneumoniae nifB genes. J ournal of Bacteriology, 169: 11201126.

35. Siddavattan $D$, Singh $M \&$ Klingmüller $W$ (1993). Structure of the nifQ gene from Enterobacter agglomerans 333 and its overexpression in Escherichia coli. Molecular and General Genetics, 239: 435440.

36. Freiberg C, Fellay R, Bairochi A, Broughton WJ, Rosenthal A \& Perret R (1997). Molecular basis or symbiosis between Rhizobium and legumes. Nature, 387: 394-401.
37. Setterquist RA, Brigle $K E$, Beynon J L, Cannon MC, Ally A, Cannon FC \& Dean DR (1988). Nucleotide sequence of the nifE and nifN genes from Klebsiella pneumoniae. Nucleic Acids Research, 16: 5215.

38. Beynon J L, Cannon MC, Buchanan-Wollaston AV, Ally A, Setterquist RA, Dean DR \& Cannon FC (1988). The nucleotide sequence of the nifT, nifY, nifX and nifW genes of K. pneumoniae. Nucleic Acids Research, 16: 9860.

39. Nicholas KB \& Nicholas J r HB (1997). GeneDoc: Analysis and visualization of genetic variation. Available at http:// www.cris.com/ Ketchup/genedoc.shtml. Accessed March 2001.

40. Schrautemeier B, Neveling U \& Schmitz S (1995). Distinct and differently regulated Mo-dependent nitrogen-fixing systems evolved for heterocysts and vegetative cells of Anabaena variabilis ATCC 29413 characterization of the $\mathrm{fdxH} 1 / 2$ gene regions as part of the nif $1 / 2$ gene clusters. Molecular Microbiology, 18: 357-369. 


\section{Appendix 1}

Comparison of the predicted amino acid sequences of the Azospirillum brasilense (ab) NifE (I), NifN (II), NifX (III) and NifQ (IV) proteins with analogous gene products from Azotobacter vinelandii (av) (4), Klebsiella pneumoniae (kp) $(37,38)$, Gluconacetobacter diazotrophicus (ad) (9), Rhodobacter capsulatus (rc) (16), Bradyrhizobium japonicum (bj) (31), Herbaspirillum seropedicae (hs) (10), Rhizobium sp (rsp) (36), and Enterobacter agglomerans (ea) (35). A black background indicates conserved residues in all aligned sequences, dark grey indicates conserved residues in at least $80 \%$ of the aligned sequences, and light grey indicates conserved residues in at least $60 \%$ of the aligned sequences. Conserved cysteine residues are indicated by black dots. Multiple alignment was done using the PILEUP program, University of Wisconsin Genetics Computer Group. The alignment editing was done using the GeneDoc program and the Dayhoff PAM 250 score table (39).

APPENDIX 1(I)

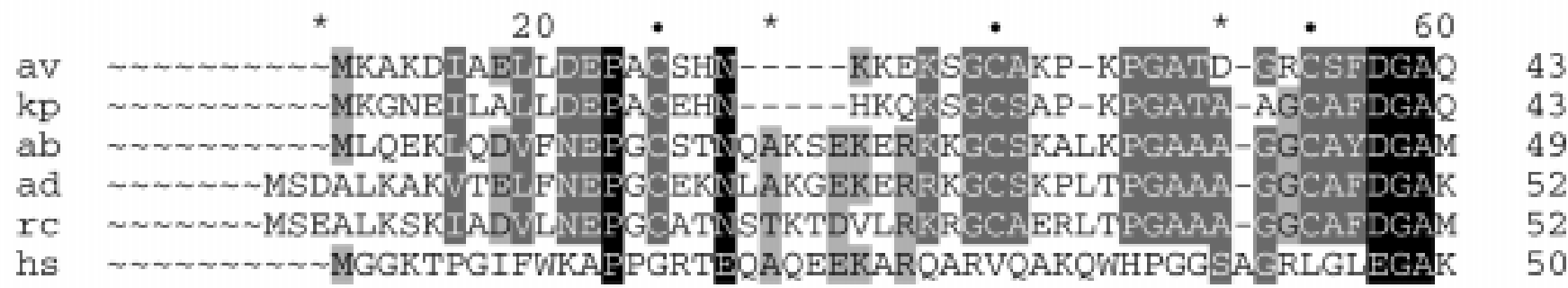

av

$\mathrm{kp}$

ab

ad

rc

hs
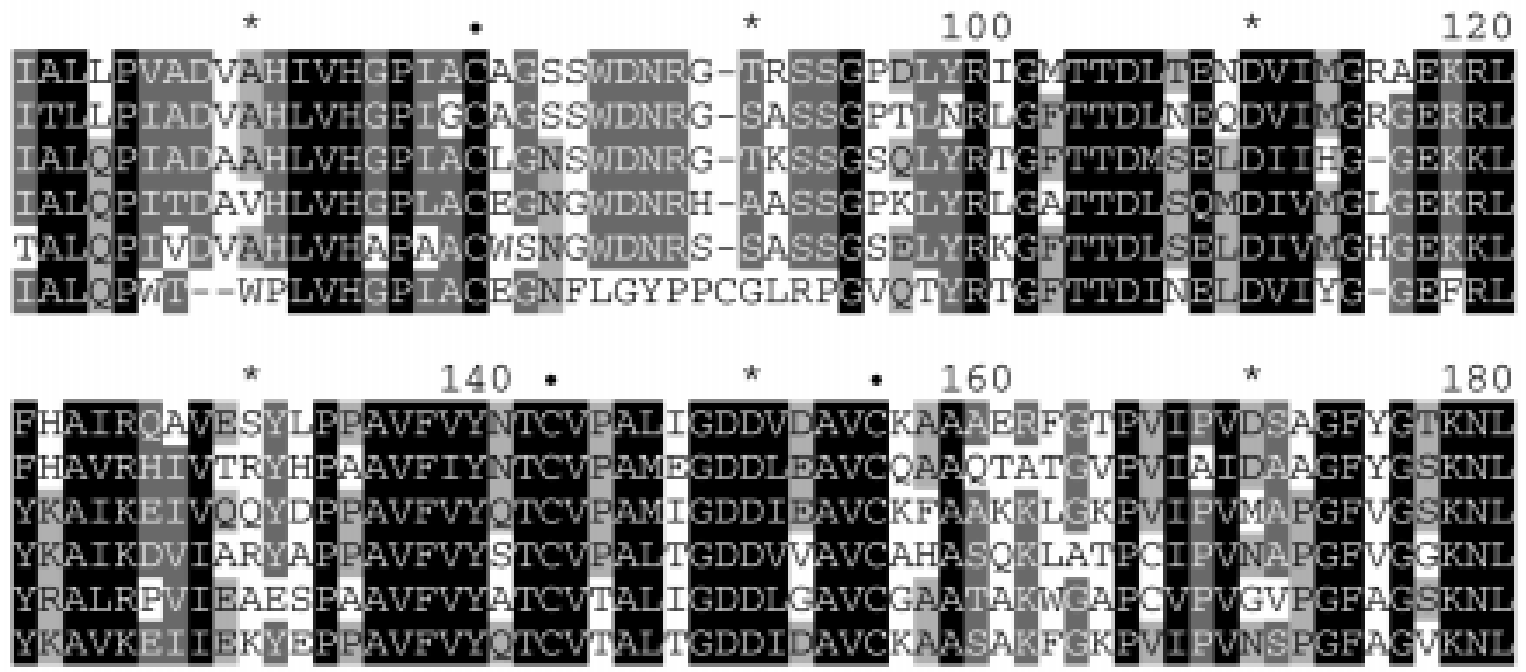
Appendix 1(I) continued

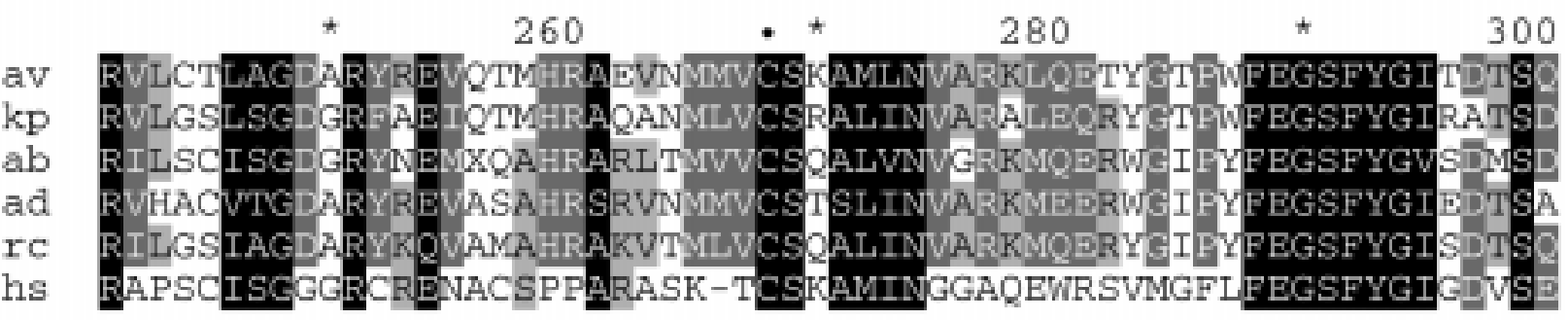

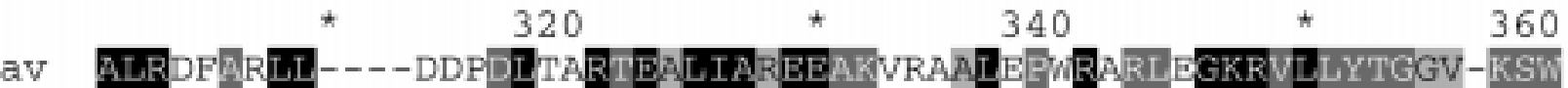

$\mathrm{kP}$ ALRQLAALL- - -GDDDLRQRTEALIAREEQAARLALQPWREQLRGRKALYTGAV-KSW ab TLRTMARMLVERGADKAIIDRTEGVIAREESEVWRRLEPYMFFDGKRVLLFTGGV-KSW ad ALRAIAGMLVARGAPADLPARA EALIAEEEARAWEAIAPYRARLEGKRVLLYTGGV-KSW IC SLRRICELLVDQGAPKDLLNRCEVLVAREEAKAWAALIKPFRPRVAGRRVLLYTGGH-KSW hs SLROIARLLVQOGGAS LMDRTEALIAVEEARAWSRLAHYKKRLAGKRVEEKDRRCEVLV

av SVVSPLCDLG-MKVATGTKKSTEEDKARIRELMGDDVKMLEGNARVLLTVDEYOADI $\mathrm{kP}$ SVVSALQDLG-MTVNATGTRKSTEEDKÖR IRELMGEDAVMLEBGNAETLLDVVYRYOADL.

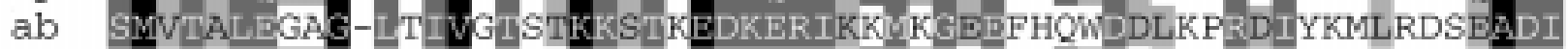
ad SIVSALQEIG-MVVVGISVRK STDNDKQK IKDLMGGDAHMVDAIPP EMYAQLRRGDADI

av

$\mathrm{kp}$

$a b$

ad

rc

hs

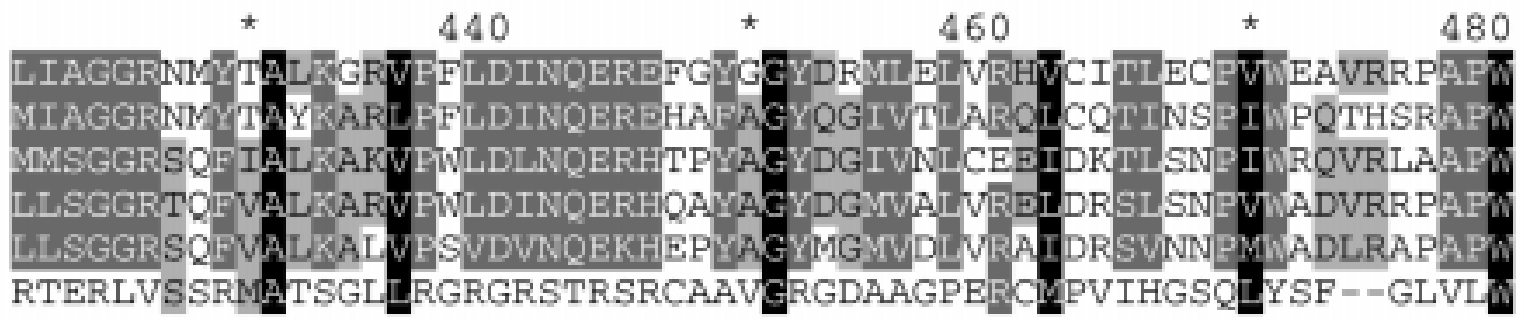

456

456

456

460

460

452

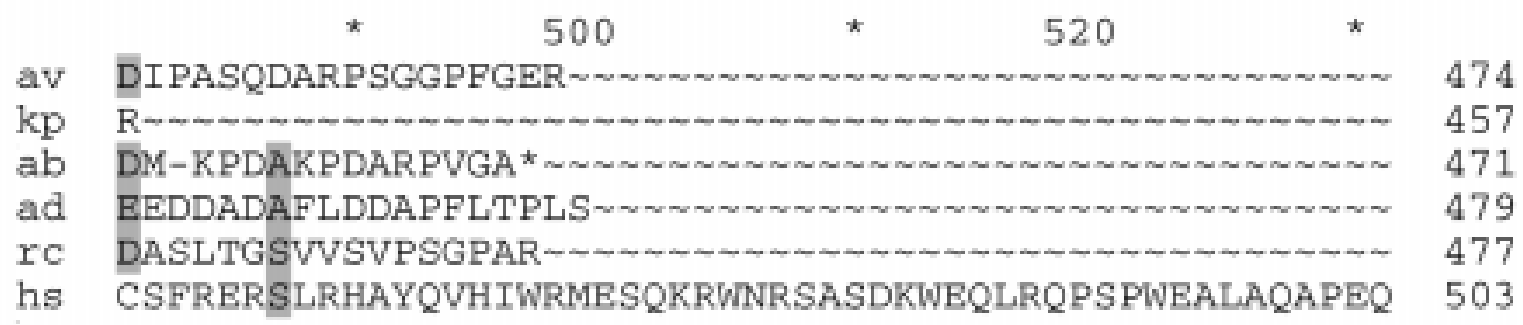

Appendix 1 continued on next page 


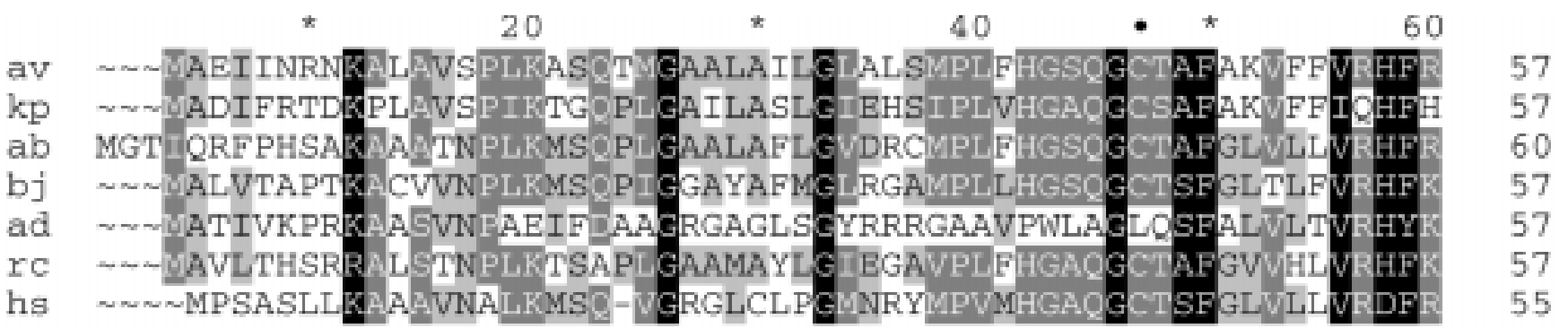

av

$\mathrm{kp}$

$a b$

bj

ad

rc

hs

av

$\mathrm{kp}$

$a b$

bj

ad

re

hs

$\mathrm{kp}$

$a b$

bj

ad

rc

hs

$\mathrm{kp}$

$a b$

bj

ad

re

hs
80

100

*

120

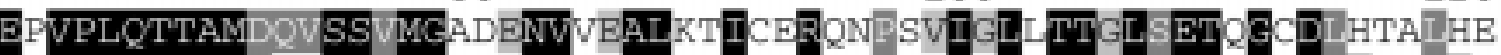
RFVPLQSTAMIPTSTIMCADGNIFTALDTLCQRNNEQAIVLLSTGL SEAGSDISRVVRQ EA I PLQTTAMDQV ST ILGGYENLEQAVRTI HERNA.PAI I GVATTGVTETKGED AGQYSL EA I PLQTTAMS EVATVLGGYENLEQA ILN I SKAAKEKI I G I STGVTETNGDDVEAYLKL

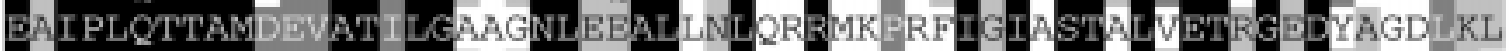
EAVPLQTTAMNEVI ILGGGGQIEEA IDNIRKAANPKF I GIASTALTETFGED IAGELRA EAIPLQTTAMN SSTLGGMENIAKAVLN IRLEAKRDI IA ICSTGLTETKGDDVNAYLRL

160

180

FRTQYEEYKDVPIVPVNTPDESECFESGF AAAVKAIVETLVPERRDQVGKRPRQVNVLCS FREEYPRHKGVA LTVNT PDF Y GSME GF SAVL ESVIEQWVPP-ĀPRPAQRNRRVNLLVS FRQRNPALAGLKLVFANTPDESGGFEDGFSARTGIVEEVV-QPSETTVK--GQINVLAG IRSAYPQLTKL PUVY TPDEK EAFQD GNEKA VARMVEVLVDRPSANGLRDPSKVNVLPG ILQRQPELADTR VFASTPDYAGALEDGWAA VSA I I ESVV-APWSPTVTSFQQVNVLPG MQVRRKDWVGTAVVHVITPDE EGGQQDGWAKAVEAIVA.ALV PVTAERD-PDLRQVTLIVP TAEAPRPGRYLTGLCPHALT-TGASQDGWMAEALAGRWESRGRADARQAD-- - LIAG

240 ANL TPGDLEYTAESI SSFGRP L I PDLSGSEGHLDENRFNALTI GGLSWAELATAGQS

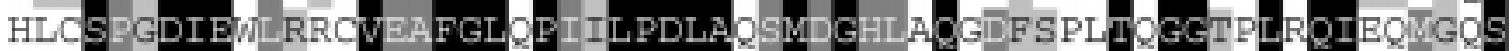
CHLSPGDVEELRDI I SSGLSFIFLPDLSL SMSGRQPD-DFTATSLGGVTVEQIASMGAS CHLT PGDLELRALL SDFG Y SFLPDLAG L D GHIPR-EFT STI I GGIDVDEIASMGRA VHOTPADIEALRDLI ESFGLYPVILPDLSG L GHVAE-NWCPTTOGGAFMEEVAQMARA SCFITAEIDEAVRMIRA FGLSPIVL PDLST LDGHL SD-DWSGHSLGGTRLDDIARIPRS CHLI PADIEEMRDIVOSFGLEPIVLPDSSWLDGHLPD-NFSPTSMGGTLAEURALGA

230

\section{0 \\ 280 \\ 300}

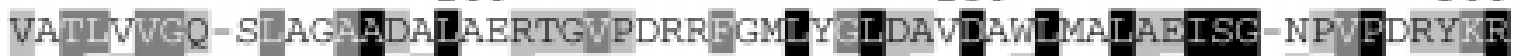

LCSFAICV-SLHRA SSLIAPRCRGEVIALPHLMTLERCDAFIHQLAKISG-RAVPEWLER ELTLVVGE-HIRVAAALELKTDVRSVFFDRLTGLASDRLVRTLSELSG-RPV PAKLR R GWTIAIGA-QNQRA AEVMTTTGVPFRVE BRLCGLHPNDDFMMFLSEISG-RPIPSKYRF VHTIAICE-HMRAPADLIGSVTGVPVLFPTLTGLANDRLMALLSRLSG-RAVPGRYRF 293 AVRLAIGE-QNRAA A PMI EDRALVPYRVEQSLTGLKVVDAFVRVLMELSGMODPPPSTKR 


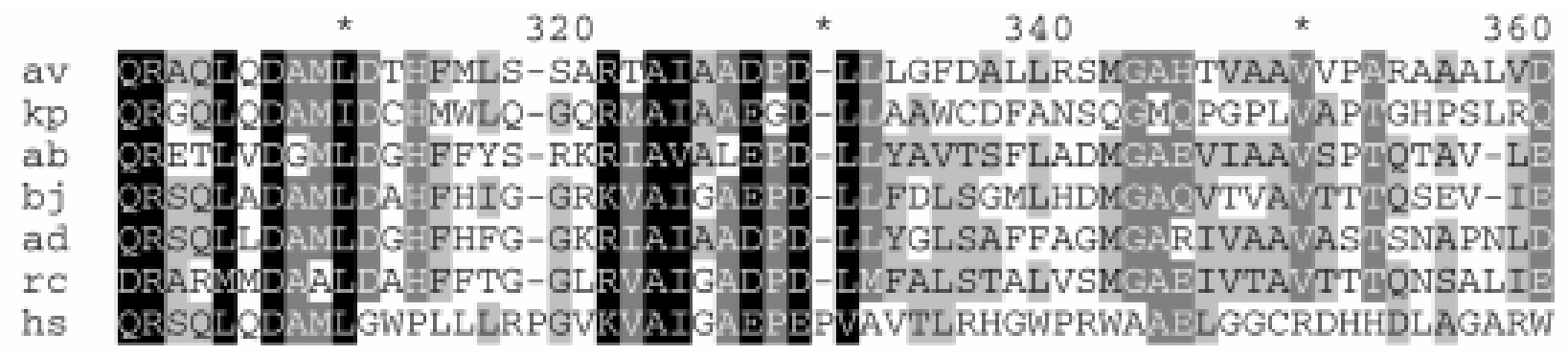

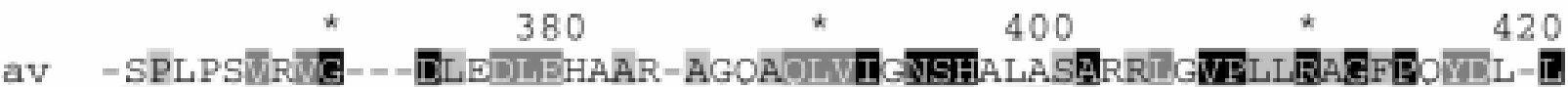

kD -LPVERWVPG---DLEDLCTLLC-AHPADLIV NSSARDLAEQFALPLVRAGFPLFDK-

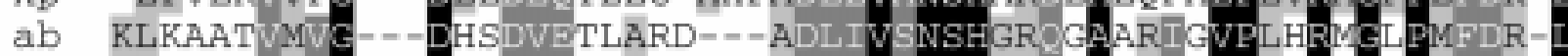

bj RIRTKEVLIG---DLEDL EGFAKEK-HCDLII HSHGRCAMGRL KVPFYRVGFPIFDR-

$\begin{array}{lrr}\text { av } & \sim \sim & - \\ \text { kp } & \sim \sim \sim & - \\ \text { ab } & \text { AG* } & 466 \\ \text { bj } & \text { SIA } & 469 \\ \text { ad } & \sim \sim & - \\ \text { rc } & \sim \sim & - \\ \text { hs } & \sim \sim & -\end{array}$




\section{APPENDIX 1(III)}

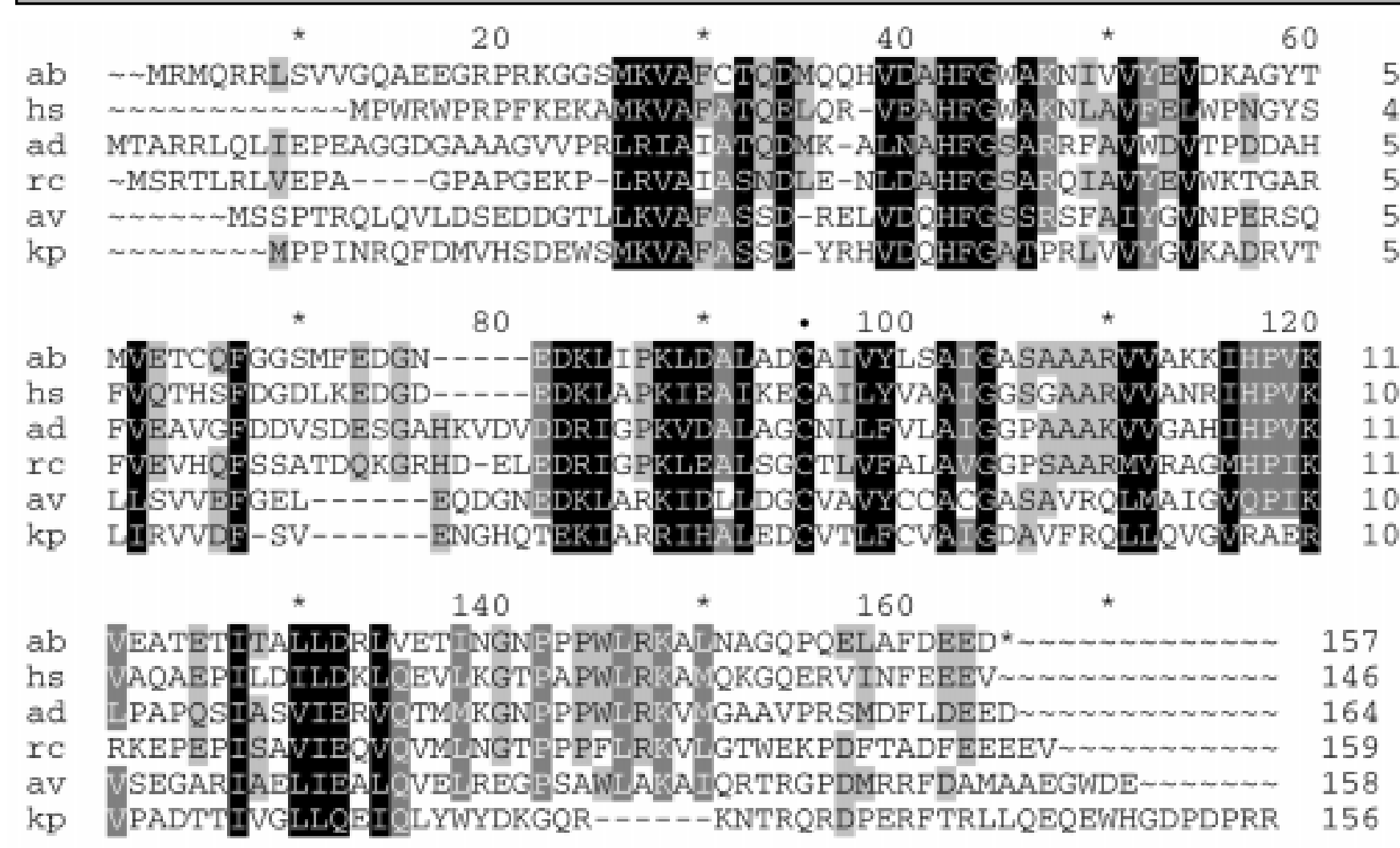

APPENDIX 1(IV)

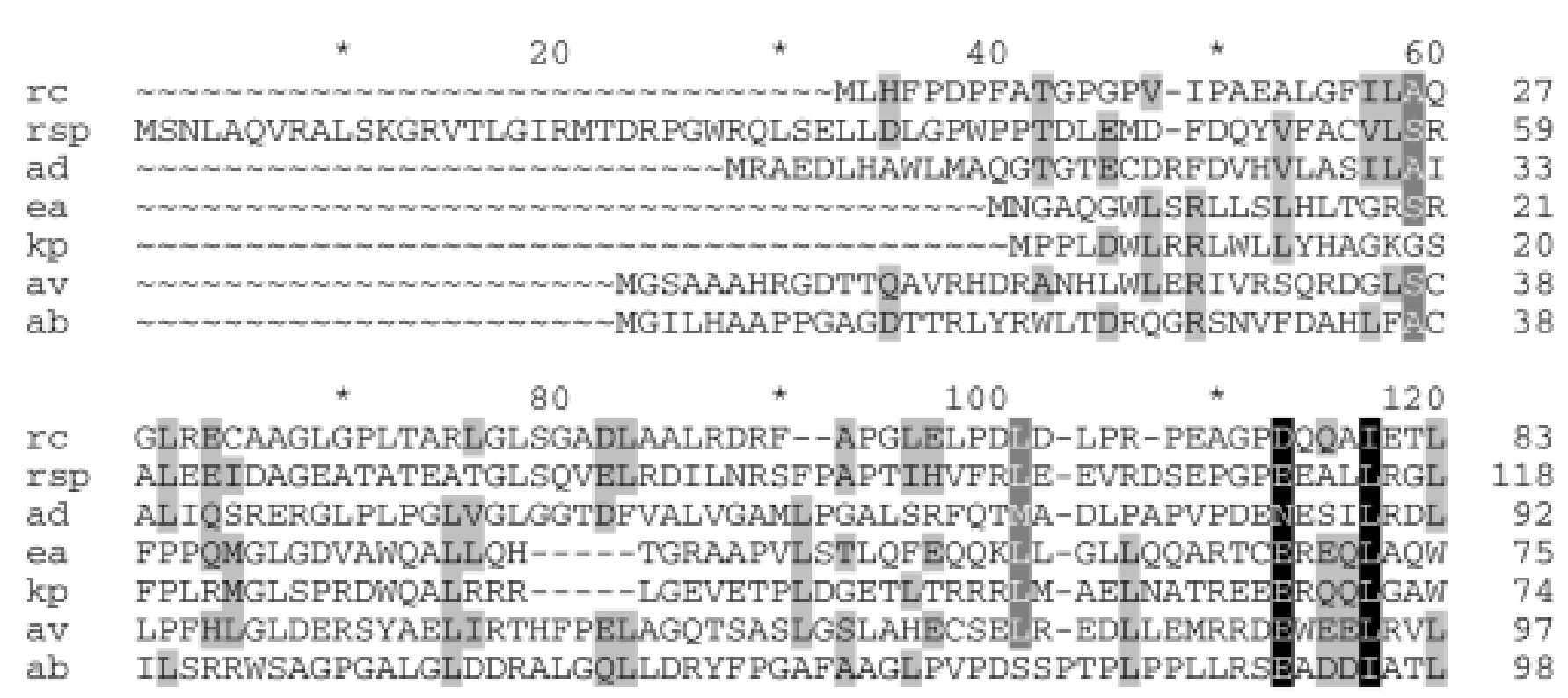


Appendix 1(IV) continued

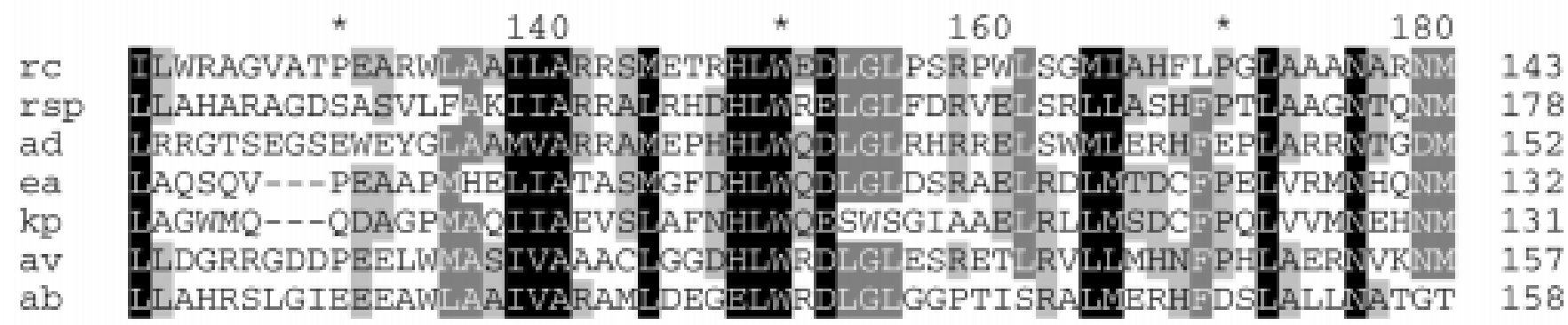

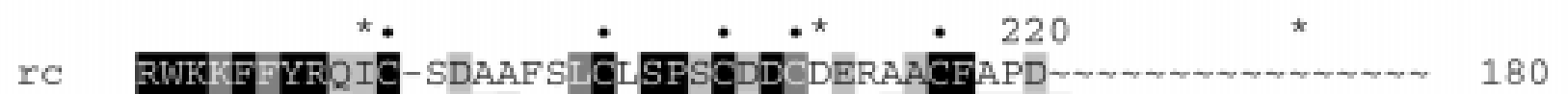

$r s p$ RWK $Y$ FRKL C-EAEGYSL CTAPSCPQCKELESCFGSGEGESASPVGKVGGEA - 230

ad KWK E FRLIC-RDEGYRLCSTPVCDECDDFDACFGAEDGESLLARTAAGRPAA 205

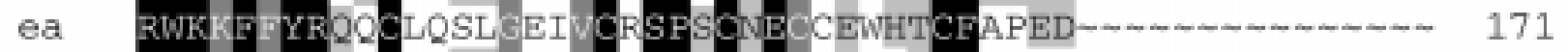

$\mathrm{kP}$ RWKKF FRQRCLLQQGEVICFSPSCDECWERSACFE 167

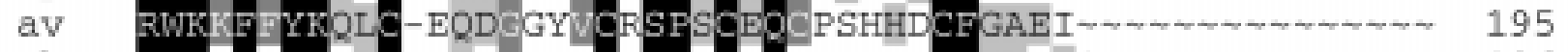

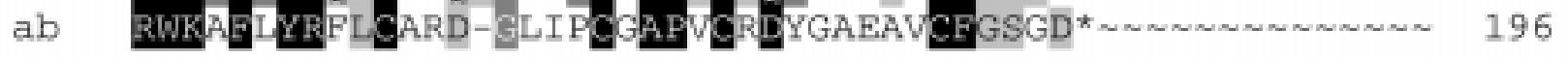




\section{Appendix 2}

Comparison of the predicted amino acid sequences of the Azospirillum brasilense (ab) Orf3 (I), Orf5 (II) and FdxA (III) proteins with analogous gene products from Azotobacter vinelandii (av) (3), Anabaena variabilis (anb) (40), Plectonema boryanum (pb) (33), Gluconacetobacter diazotrophicus (ad) (9), Rhodobacter capsulatus (rc) (16), Azorhizobium caulinodans (ac) (32) Rhizobium sp NGR234 (rsp) (36), and Herbaspirillum seropedicae (hs) (10). A black background indicates conserved residues in all aligned sequences, dark grey indicates conserved residues in at least $80 \%$ of the aligned sequences, and light grey indicates conserved residues in at least $60 \%$ of the aligned sequences. Multiple alignment was done using the PILEUP program, University of Wisconsin Genetics Computer Group. The alignment editing was done using the GeneDoc program and the Dayhoff PAM 250 score table (39).

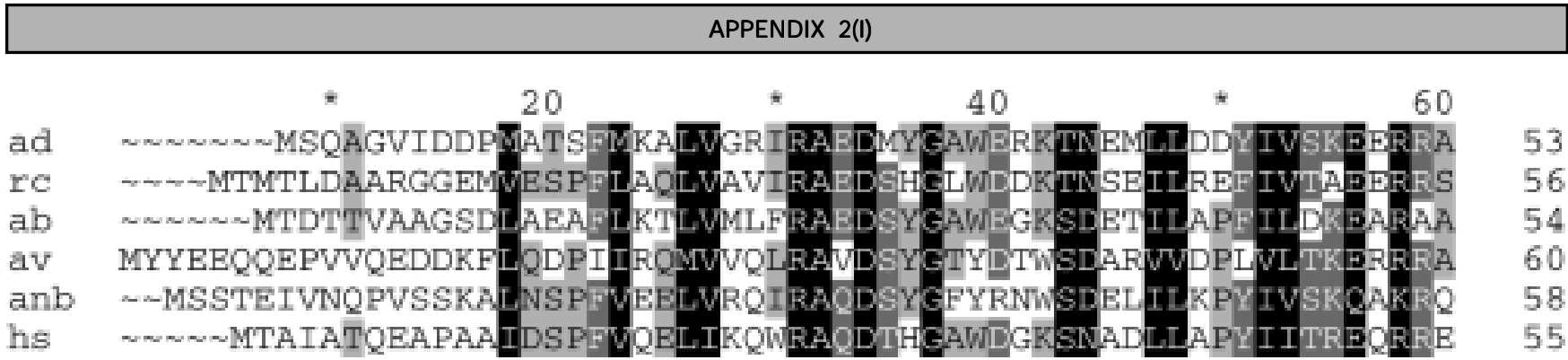
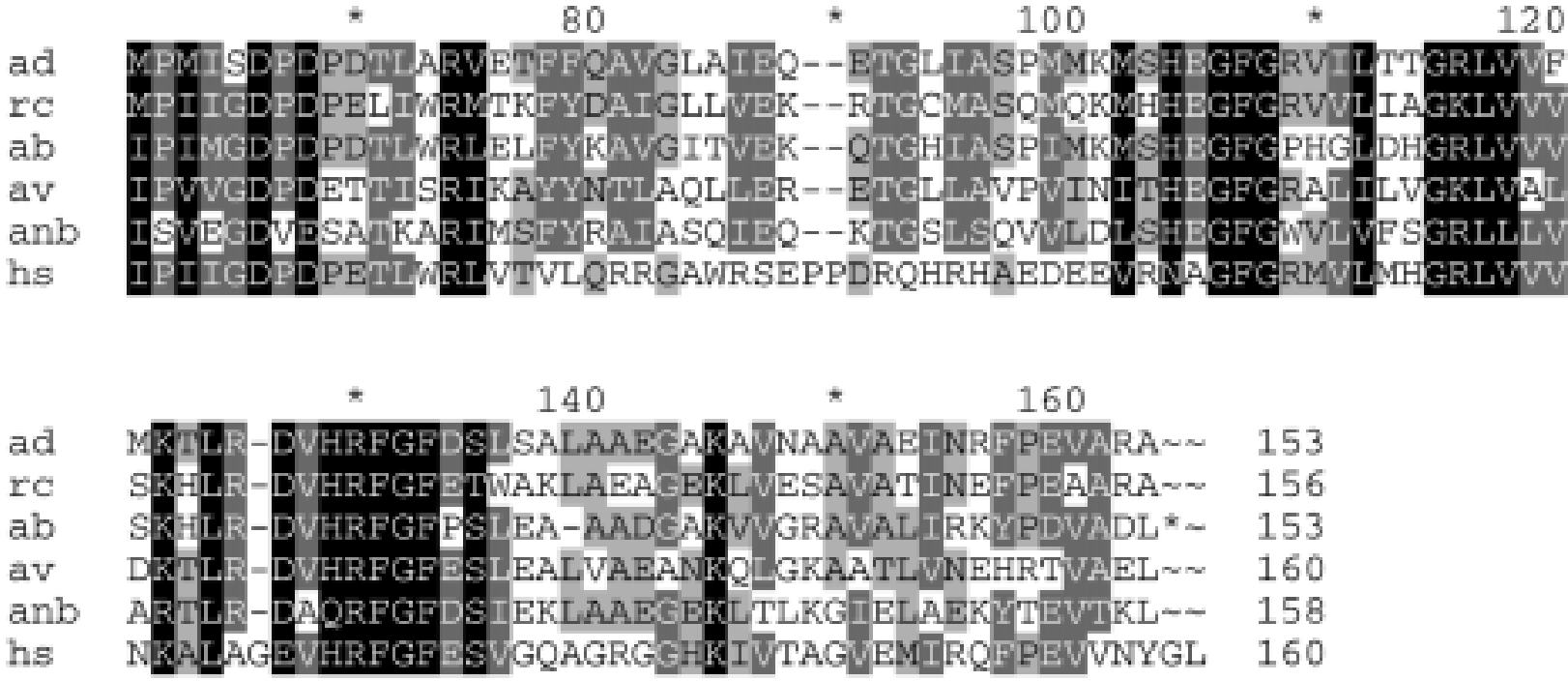
APPENDIX 2(II)

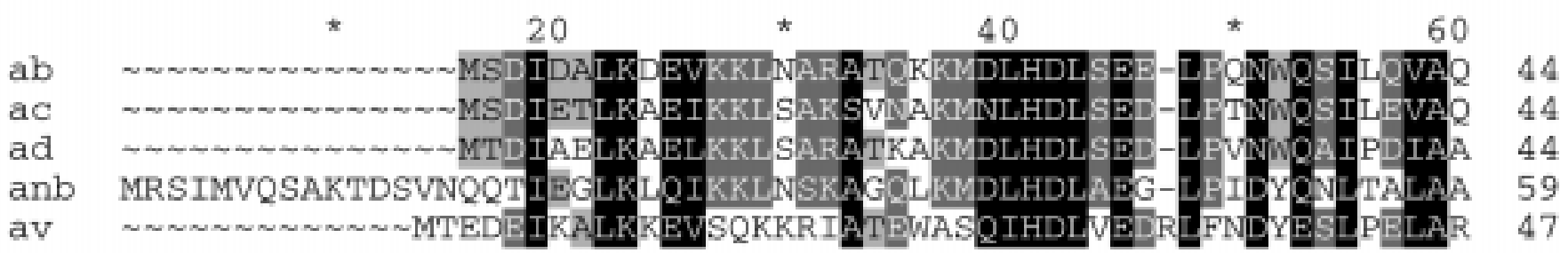

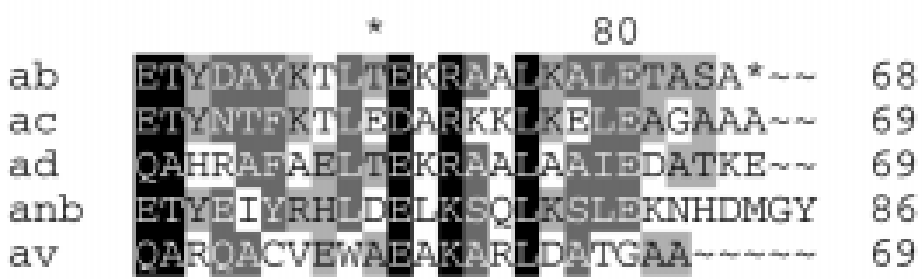

APPENDIX 2(III)

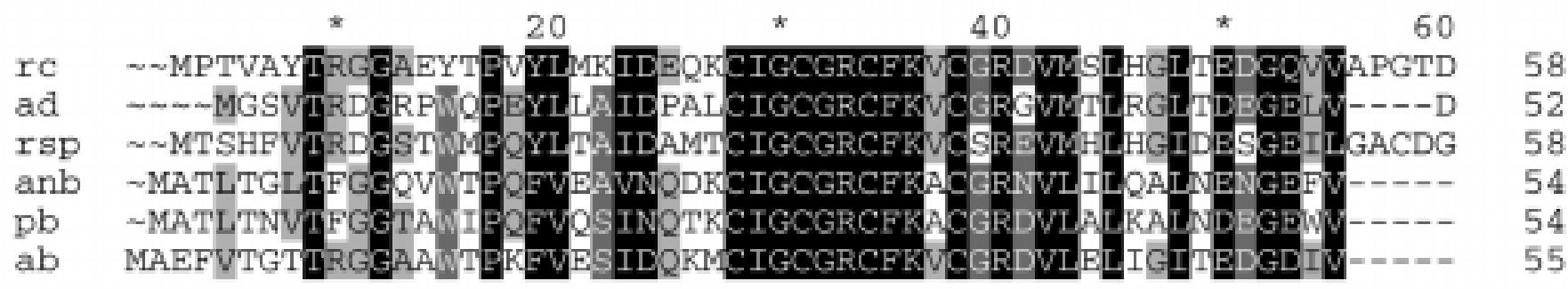

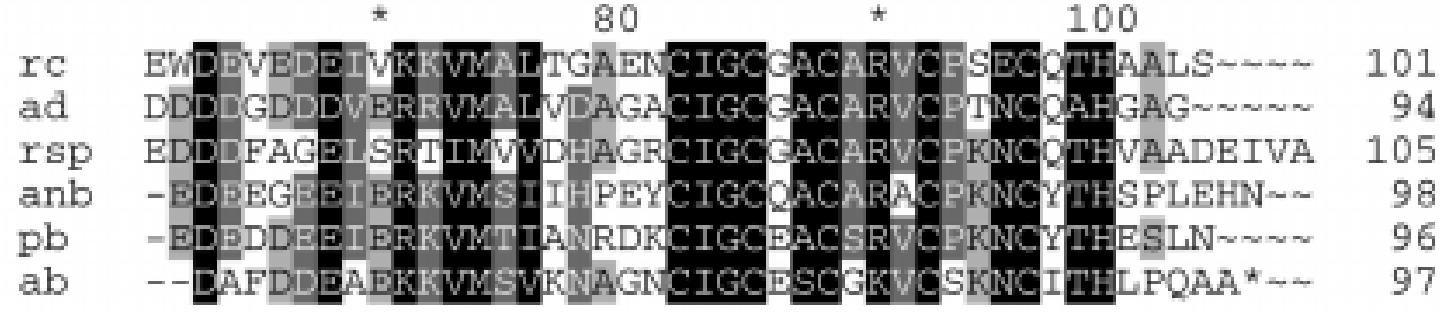

